\title{
QUALITY OF LIFE DYNAMICS IN PATIENTS WITH DIABETIC FOOT SYNDROME WITH COMBINED TREATMENT BY PHYSIOTHERAPY AND AUTOLOGOUS PLASMA*
}

\author{
T. O. Kharchenko' ${ }^{1}$, O. K. Melekhovets ${ }^{1}$, Iu. V. Melekhovets ${ }^{1}$, \\ A. S. Radko ${ }^{1}$, N. V. Kalashnyk ${ }^{1}$, R. S. N. Shu ${ }^{2}$ \\ ${ }^{1}$ Sumy State University, Ministry of Education of Ukraine, Sumy, Ukraine; \\ ${ }^{2}$ University of Duisburg-Essen, Essen, Germany \\ kharchenko24t@gmail.com
}

According to the International Diabetes Federation in Ukraine, the number of patients with diabetes mellitus (DM) between the ages of 20 and 79 years is about $7 \%$ of the total population [1], with an increasing estimate of approximately 629 million patients worldwide by 2045 [2]. DM is a major cause of blindness, kidney failure, heart attacks, stroke and lower limb amputation [3]. DM related ulcers rank first among lower extremity ulcers, which in most cases result to sensitivity loss [4]. Diabetic neuro- and angiopathy are major factors causing diabetic foot ulcers (DFU) [5], resulting from ischemic reduction of oxygen and nutrients supply to the ulcerous site, thus hindering the optimal wound healing process in such patient cohorts. In oxygen and nutrient deprived states, epithelial cells in the ulcerous site fail to release vital healing factors such as vascular endothelial growth factor (VEGF) and platelet-derived growth factor (PDGF) [6]. Some growth factors such as epidermal growth factor (EGF), granulocyte-colony stimulating factor (GCSF), nerve growth factor (NGF) and VEGF have been evaluated in patients with DFU $[7,8]$. In recent studies a pool of growth factors from autologous plasma rich growth factors were analyzed $[9,10]$.

Health Related Quality of life (HRQoL) research has become an integral part of modern medicine. The World Health Organization (WHO) recommends the use of the following basic HRQoL criteria: physical, psychological, level of autonomy, social life and environment [11], thus the EuroQol-5D-5L (Ukrainian Version for Ukraine) questionnaire developed by the European Quality of Life Study (EuroQol Group), which was officially approved,

* The study was conducted as part of a scientific program «Scientific justification for improving health care and public health quality», state registration number 0110U07572.

Institution, which financed the research: Ministry of Health of Ukraine.

The authors assume responsibility for the published work.

The authors guarantee absence of competing interests and their own financial interest when carrying out the research and writing the article.

The manuscript was received by the editorial staff 29.10.2019. 
was used to assess patients' quality of life in this study. This questionnaire demonstrates both physical and psycho-emotional indicators as well as permits quality of life assessments at different stages of the treatment process.
The aim of this study is to evaluate the efficacy of combined photodynamic therapy (PDT) and plasma rich growth factors (PRGFT) therapy on the quality of life improvement in patients with diabetic foot syndrome.

\section{MATERIALS AND METHODS}

The study included 61 outpatients with type $2 \mathrm{DM}$ with Wagner grade II diabetic foot syndrome, who gave informed consent to participate in the study in accordance with the world medical association (WMA) Helsinki Declaration - Ethical Principles for Medical Research Involving Human Subjects, 2013.

The inclusion criteria for the groups were the presence of trophic ulcers with an area $\leq 5 \mathrm{~cm}^{2}\left(1^{\text {st }}\right.$ group $-4.39 \pm 0.5 \mathrm{~cm}^{2}, 2^{\text {nd }}$ group $\left.4.45 \pm 0.45 \mathrm{~cm}^{2}\right), \mathrm{HbA} 1 \mathrm{c} \leq 7 \%\left(1^{\text {st }}\right.$ group $\left.6,9 \%, 2^{\text {nd }}-6,8 \%\right)$.

Depending on the regimen of the proposed therapy, patients were divided into two groups comparable in clinical status, age $\left(1^{\text {st }}\right.$ group $60,53 \pm 9,98$ years, $2^{\text {nd }}-62,23 \pm 8,64$ years $)$, gender $\left(1^{\text {st }}\right.$ group - males $=7$, females $=23$; $2^{\text {nd }}-$ males $=8$, females $=23$ ) .

Antihyperglycemic treatment in the both groups $(\mathrm{n}=61)$ included combination therapy: long-acting insulin + metformin $-22.95 \%$ (14 patients), sulfonylurea + metformin $63.93 \%$ (39 patients), dipeptidyl peptidase 4 inhibitor + metformin $-6.56 \%$ (4 patients), sulfonylurea + sodium - glucose cotransporter 2 inhibitor $-3.28 \%$ (2 patients), and monotherapy with metformin $-3.28 \%$ (2 patients) [12].

Glucose-lowering therapy was supplemented with antibiotics (according to the results of microbiological examination of the discharge), while wound debridement ( $1^{\text {st }}$ group), in the $2^{\text {nd }}$ group $(n=31)$ standard therapy $(\mathrm{ST})$ was supplemented by PDT and PRGFT procedures.

Initially patients were prescribed PDT using a laser machine "Lika-Surgeon M" (Photonica-Plus, Ukraine) with a wavelength of $660 \mathrm{~nm}$ in a continuous regiment every other day (8 procedures). Methylene blue $1 \%$ aqueous solution as a photosensitizer was used.

After 2 weeks post wound surface cleaning and transitioning to the granulation phase, PRGFT was added to treatment process. The procedures were performed once a week, a total of 4 treatment course procedures.
In order to assess quality of life dynamics, all patients were interviewed using the EuroQol-5D-5L survey instrument, which consists of a EQ-5D descriptive system followed by the EQ visual analogue scale (EQ VAS) [13, 14]. In the descriptive section, health status is measured in five dimensions (5D); mobility, self-care, usual activities, pain/discomfort, and anxiety/depression. Scores from 1 to 5 were divided into two subgroups, where scores 1,2 , and 3 corresponded to the overall quality of life scores above average; and 4 and 5 were below average.

The S(AD)SAD (Size (Area, Depth), Sepsis, Arteriopathy, Denervation) classification was used to evaluate clinical status dynamics, which included 4 categories of 2 points, with a maximum of 30 points characterizing the most severe condition [15]. The evaluation criteria included: size $(0-$ skin intact; $2-$ $\left.<1 \mathrm{~cm}^{2} ; 4-1-3 \mathrm{~cm}^{2} ; 6->3 \mathrm{~cm}^{2}\right)$ and depth of wound surface $(0-$ skin intact; $2-$ superficial - involving skin and subcutaneous tissues but not reaching the tendon, periosteum or joint capsule; 4 - penetrating the tendon, periosteum or joint capsule; 6 - involving bone or joint spaces), presence of infectious process $(0-$ no infection; 2 - superficial infection, indicated by slough or exudate, but without clinical suspicion of cellulitis or osteomyelitis, also tinea pedis; 4 - cellulitis; 6 - osteomyelitis), degree of angiopathy (evaluated by the anklebrachial index (ABI), where 1 point was for $0.7-0.9$, and 2 points - for $\leq 0.6$ ) and neuropathy (assessed using the Neurological Deficit Scale - NDS, where a score of 0 indicated no neuropathy, a score of 1 - moderate neuropathy, and a score of 2 - severe neuropathy).

The survey was performed in both groups at the beginning of treatment (EuroQol 1 and $\mathrm{S}(\mathrm{AD}) \mathrm{SAD}-1$ ), after 2 weeks (EuroQol -2 and S (AD) SAD -2 ), after 6 weeks of treatment (EuroQol -3 and $\mathrm{S}$ (AD) $\mathrm{SAD}-3)$. 
To evaluate trophic ulcer healing dynamics, a Lesion Meter app was used. Measurements were made at each patient visit. Data for each patient were automatically stored in separate folders.

Statistical analysis was performed with Windows 10 - Office Professional Plus software (Agreement ID: V0731528) with the use of parametric and non-parametric methods of variation statistics. Shapiro-Wilk test was applied to test normality of parameters in the study. Two-sample Student's t-test was used to determine the significantly changed between groups with a probability mean of 0.05 . Relative change method was used to compare ulcer healing dynamics in the two groups.

\section{RESULTS AND THEIR DISCUSSION}

Clinical status evaluation in the $1^{\text {st }}$ group demonstrated the average total score at baseline to be 13.97 points according to S(AD) SAD classification, after 2 weeks - 13.20 (improvement by $5.51 \%$ ), after 6 weeks -7.83 (improvement by $43.95 \%)(\mathrm{p}>0,05)$ (Tab. 1).

Clinical status improvement in patients in the $1^{\text {st }}$ group after PDT was achieved by a $19.89 \%$ inflammation reduction. Other S(AD) SAD categories had significant positive dynamics. The results obtained following PRGFT stimulation of the epithelium in the second stage showed a $30.95 \%$ decrease of the ulcer defect area, depth - by $5.00 \%$, improvement of angiopathy indices - by $28.93 \%$ and neuropathy signs $-15.54 \%(\mathrm{p}>0,05)$.

In the $2^{\text {nd }}$ group, baseline average total score was 13.91 points, after 2 weeks -12.29 (improvement by $11.65 \%$ ), after 6 weeks 6.36 points (improvement by $54.27 \%)(p>0,05)$ (Tab. 2).

The same positive clinic dynamics in the $2^{\text {nd }}$ group post PDT were achieved with more obvious improvement of up to $42.52 \%$, while positive dynamics were observed in other categories. PRGFT performed at the second stage as part of the combined treatment resulted in: $53.05 \%$ decrease of defective ulcer area, depth - by $11.00 \%$, improvement indices in angiopathy category - by $43.29 \%$, in the neuropathic category - by $22.10 \%(\mathrm{p}<0,05)$.

An estimation of quality of life dynamics in the $1^{\text {st }}$ group showed significant improvement in «mobility» by $14.78 \%$ after 2 weeks, after 6 weeks - by $27.58 \%$; in the "usual activities» category - by $2.09 \%$ after 2 weeks, and after

S(AD)SAD evaluation of ulcers healing dynamics

Table 1 in the 1st group

\begin{tabular}{c|c|c|c|c|c}
\hline Group & $\begin{array}{c}\text { Area of } \\
\text { the wound } \\
\text { surface }\end{array}$ & $\begin{array}{c}\text { Depth of } \\
\text { the wound } \\
\text { surface }\end{array}$ & $\begin{array}{c}\text { Infection } \\
\text { process }\end{array}$ & Angiopathy & Neuropathy \\
\hline At baseline & 4,2 & 2,0 & 3,87 & 1,97 & 1,93 \\
\hline 2 weeks & 4,2 & 2,0 & 3,10 & 1,97 & 1,93 \\
\hline 6 weeks & $2,9^{*}$ & 1,9 & $0^{*}$ & 1,4 & 1,63 \\
\hline
\end{tabular}

* statistically significant difference compared to the baseline $(p<0.05)$.

\section{S(AD)SAD evaluation of ulcers healing dynamics}

Table 2 in the 2nd group

\begin{tabular}{c|c|c|c|c|c}
\hline Group & $\begin{array}{c}\text { Wound } \\
\text { Surface Area }\end{array}$ & $\begin{array}{c}\text { Wound } \\
\text { Surface } \\
\text { Depth }\end{array}$ & $\begin{array}{c}\text { Infection } \\
\text { process }\end{array}$ & Angiopathy & Neuropathy \\
\hline At baseline & 4,26 & 2,0 & 3,81 & 1,94 & 1,9 \\
\hline 2 weeks & 4,26 & 2,0 & $2,19^{*}$ & 1,94 & 1,9 \\
\hline 6 weeks & $2,0^{*}$ & $1,78^{*}$ & $0^{*}$ & $1,1^{*}$ & $1,48^{*}$ \\
\hline
\end{tabular}

* statistically significant difference compared to the baseline $(p<0.05)$. 
EuroQol-5D-5L evaluation dynamics in the 1st group

\begin{tabular}{c|c|c|c|c|c}
\hline 1st group & At baseline & $\begin{array}{c}\text { After } \\
\mathbf{2} \text { weeks }\end{array}$ & $\begin{array}{c}\boldsymbol{\Delta} \\
\text { (2 weeks } \\
\text { and } \\
\text { baseline) }\end{array}$ & $\begin{array}{c}\text { After } \\
\mathbf{6} \text { weeks }\end{array}$ & $\begin{array}{c}\boldsymbol{\Delta} \\
\text { (6 and } \mathbf{\text { weeks) }}\end{array}$ \\
\hline Morbility & 2,03 & 1,73 & -15 & $1,47^{*}$ & -28 \\
\hline Self-care & 2,53 & 2,53 & 0 & $1,90^{*}$ & -25 \\
\hline Usual activities & 1,43 & 1,4 & -2 & 1,37 & -5 \\
\hline Pain / discomfort & 3,03 & 2,73 & -10 & $2,27^{*}$ & -25 \\
\hline Anxiety/depression & 3,9 & 3,9 & 0 & $3,23^{*}$ & -17 \\
\hline VAS & 41,73 & $58,33^{*}$ & 40 & $62,37^{*}$ & 49 \\
\hline
\end{tabular}

* statistically significant difference compared to the baseline $(p<0.05)$.

EuroQol-5D-5L evaluation dynamics in the 2nd group

\begin{tabular}{c|c|c|c|c|c}
\hline $\mathbf{2}^{\text {nd }}$ group & At baseline & $\begin{array}{c}\text { After } \\
\mathbf{2} \text { weeks }\end{array}$ & $\begin{array}{c}\boldsymbol{\Delta} \\
\mathbf{2} \text { weeks } \\
\text { and } \\
\text { baseline) }\end{array}$ & $\begin{array}{c}\text { After } \\
\mathbf{6} \text { weeks }\end{array}$ & $\begin{array}{c}\boldsymbol{\Delta} \\
\mathbf{2} \text { and } \\
\text { weeks) }\end{array}$ \\
\hline Morbility & 2,0 & $1,65^{*}$ & -18 & $1,13^{*}$ & -44 \\
\hline Self-care & 2,42 & 2,23 & -8 & $1,74^{*}$ & -28 \\
\hline Usual activities & 1,42 & 1,29 & -9 & $1,1^{*}$ & -23 \\
\hline Pain / discomfort & 2,97 & 2,52 & -15 & $1,97^{*}$ & -34 \\
\hline Anxiety/depression & 3,9 & $3,13^{*}$ & -20 & $1,23^{*}$ & -69 \\
\hline VAS & 41 & $58,55^{*}$ & 43 & $71,55^{*}$ & 75 \\
\hline
\end{tabular}

* statistically significant difference compared to the baseline $(p<0.05)$.

6 weeks - by $4.19 \%$; in "pain/discomfort» by $9.9 \%$ after 2 weeks, after 6 weeks - by $25.08 \%(\mathrm{p}>0,05)$. In the "self-care» and «anxiety/depression" categories, significant improvement in the quality of life was achieved only after 6 weeks - by $24.9 \%$ and $17.18 \%$ $(p>0,05)$, respectively (Tab. 3).

In the $2^{\text {nd }}$ group, quality of life dynamics after PDT demonstrated a $17.5 \%$ improved average score in «mobility», $9.15 \%$ in «usual activities» and by $15.15 \%$ in the "pain/discomfort» categories. Following PRGFT, improvement was achieved by $43.5 \%$ in the "physical activity» category, $22.54 \%$ in the "household activity" and by $33.67 \%$ in the "pain/discomfort» categories $(p<0,05)$ (Tab. 4).

Unlike patients in the $1^{\text {nd }}$ group, earlier positive quality of life dynamics in the $2^{\text {nd }}$ group was obtained after PDT in the "anxiety/depression» and «self-care» categories by $19.74 \%$ and $7.85 \%$ respectively, with further improvement after PRGFT by $68.46 \%$, and in the "self-care» after 6 weeks - by $28.09 \%(\mathrm{p}>0.05)$.

Further quality of life evaluation with Visual Analog Scale VAS in the $1^{\text {st }}$ group revealed a baseline total score of 41.73 points, after 2 weeks' -58.33 score points and after 6 weeks -62.37 score points, with appropriate improvement by $28.46 \%$ and $33.09 \%$ after standard treatment $(\mathrm{p}<0,05)$. In the $2^{\text {nd }}$ group, $29.97 \%$ post PDT and $42.69 \%$ post PRGFT improvements were obtained $(\mathrm{p}<0,05)$.

Discussion. Non-healing trophic ulcers in patients with diabetes mellitus significantly impairs quality of life and inhibits both physical and psychological status. Using PDT as combined therapy for chronic ulcers in DM patients resulted in complete purification of the wound surfaces in shorter time periods compared to ST. This thus influenced all quality of life indicators according to EuroQol scale, including the category of «mobility» $(2.72 \% \mathrm{im}$ - 
provement), «self-care» (7.85\%), "usual activities» (7.06\%), «pain/discomfort» (5.25\%) and «anxiety/depression» category (9.74\%) improvements $(p<0,05)$.

Based on contemporary data [9, 10], PRGFT was included in the combined treatment scheme post PDT-course to stimulate epithelialization of the wound defects in patients of the $2^{\text {nd }}$ group. The effectiveness of the proposed algorithm was confirmed by the improvement of all categories of the EuroQol scale: «mobility» - by $18 \%$, "self-care» - by $9 \%$, «usual activities» - by $9 \%$, «pain/discomfort» $15 \%$ and "anxiety/depression» categories by $20 \%(\mathrm{p}<0.05)$
Advantages of using PDT and PRGFT in sequential stages of wound healing reveals new therapeutic perspectives in regenerative medicine. This treatment scheme has obvious advantages compared to the traditional debridement. Both components have demonstrated properties for active stimulation of cell proliferation, differentiation and angiogenic potential. This approach permits healing time reduction, thus improving quality of life of DM patients.

As limitations, only local wound status dynamic effects on quality of life were evaluated, while other general conditions were not considered in the current study, aspects envisaged in future studies.

\section{CONCLUSIONS}

Photodynamic and autologous plasma rich growth factors combined therapy is preferable vis-a-vis standard care in the treatment and improvement of quality of life in outpatients with diabetic foot syndrome.

\section{REFERENCES}

1. Diabetes prevalence (\% of population ages 20 to 79 ), available at: https://data.worldbank.org/indicator/SH. STA.DIAB.ZSend $=2017 \&$ start $=2017 \&$ type $=$ shaded\&vie $w=$ map

2. International Diabetes Federation. IDF Diabetes Atlas. 8th Edition 2017, available at: http://diabetesatlas.org/ $I D F \_D i a b e t e s \_A t l a s \_8 e_{-}$interactiv $e_{-} E N$

3. World Health Organization, Facts and Figures About Diabetes. 2014, available at: http://www.who.int/mediacentre/factsheets/fs312/en/.

4. Gonsalves CF. Techniq Vascular Intervent Radiol 2003; 6: $132-136$.

5. Wu SC, Driver VR, Wrobel JS, Armstrong DG. Vascular Health Risk Management 2007; 3: 65-76.

6. Lobo R, Kiernan TJ, Jaff MR. J Cardiovasc Surg 2013; 54: 671-678.

7. Singla S, Kumar A, Singla M. Indian J Surg 2012; 74: 451-455.
8. Cruciani M, Lipsky BA, Mengoli C, de Lalla F. Cochrane Database Systematic Rev 2013; 8: CD006810.

9. Martinez-Zapata MJ, Marti-Carvajal AJ, Sola I, et al. Cochrane Database Systematic Rev 2012; 10: CD006899.

10. Saad Setta H, Elshahat A, Elsherbiny K, et al. Intern Wound J 2011; 8: 307-312.

11. WHO. Soc Sci Med 1995; 41(10): 1403-1409.

12. American Diabetes Association. Diabetes Care 2020; 43(1): S98-S110.

13. EQ-5D-5L, available at: https://euroqol.org/eq-5d-instrumen/eq-5d-5l-about/.

14. Whynes DK. Health and Quality of Life Outcomes 2008; 6: 94. doi:10.1186/1477-7525-6-94.

15. Treece KA, Macfarlane RM, Pound N, et al. Diabet Med 2004; 21(9): 987-991. doi: 10.1111/j.1464-5491.2004. 01275.x 


\title{
QUALITY OF LIFE DYNAMICS IN PATIENTS WITH DIABETIC FOOT SYNDROME WITH COMBINED TREATMENT BY PHYSIOTHERAPY AND AUTOLOGOUS PLASMA
}

O. Kharchenko', O. K. Melekhovets ${ }^{1}$, Iu. V. Melekhovets ${ }^{1}$, A. S. Radko', V. Kalashnyk ${ }^{1}$, R. S. N. Shu ${ }^{2}$

${ }^{1}$ Sumy State University, Ministry of Education of Ukraine, Sumy, Ukraine; ${ }^{2}$ University of Duisburg-Essen, Essen, Germany kharchenko24t@gmail.com

Introduction. Diabetic neuro- and angiopathy are major factors causing diabetic foot ulcers. Ischemia reduces oxygen and nutrients supply to wounds. In oxygen and nutrients deprived conditions, epithelial cells in wounds fail to sufficiently release important wound healing factors such as vascular endothelial growth factor (VEGF) and platelet-derived growth factor (PDGF). In recent studies a pool of growth factors from autologous plasma rich growth factors were analyzed. The aim of the study is to evaluate the efficacy of combined photodynamic (PDT) and autologous plasma rich growth factor therapy (PRGFT) on quality of life improvements in patients with diabetic foot syndrome.

Materials and methods. 61 outpatients with type 2 diabetes mellitus and Wagner grade II diabetic foot syndrome were included in this study. Patients of the $1^{\text {st }}$ group $(n=30)$ received standard therapy $(\mathrm{ST})$, in the $2^{\text {nd }}$ group (n = 31) ST was supplemented by PDT and PRGFT.

Results. Using PDT in combined therapeutic management of chronic ulcer in patients with DM resulted in complete purification of the wound surfaces during shorter time durations vis-a-vis standard therapy, thus influencing all quality of life indicators according to EuroQol scale, including the category of «mobility» (improvement by $2.72 \%$ ), "self-care» (by $7.85 \%$ ), «usual activities» (by $7.06 \%$ ), "pain/discomfort» (by $5.25 \%$ ) and "anxiety/depression" categories (by $19.74 \%$ ). PRGFT was included in the combined treatment scheme post PDT-course to stimulate epithelialization of wound defects in patients of the $2^{\text {nd }}$ group. Efficacy of this combined algorithm was confirmed by overall EuroQol scale category improvements: «mobility» — by $18 \%$, "self-care» — by $9 \%$, «usual activities» - by $9 \%$, «pain/discomfort» $15 \%$ and «anxiety/depression» categories by $20 \%$.

Conclusions. Combined photodynamic and autologous plasma rich growth factor therapy is preferable to standard therapy in the therapeutic management and improvement of quality of life in outpatients with diabetic foot syndrome.

Key words: Diabetes mellitus, diabetic foot, photodynamic therapy, autologous plasma.

\section{ДИНАМІКА ЯКОСТІ ЖИТТЯ \\ У ХВОРИХ З СИНДРОМОМ ДИАБЕТИЧНОЇ СТОПИ ПРИ КОМБІНОВАНОМУ ЛІКУВАННІ 3 ВИКОРИСТАННЯМ ФІЗІОТЕРАПІЇ ТА АУТОЛОГІЧНОЇ ПЛАЗМИ}

\author{
Харченко Т. О. ${ }^{1}$, Мелеховець О. К. ${ }^{1}$, Мелеховець Ю. В. ${ }^{1}$ \\ Радько А. С. ${ }^{1}$, Калашник Н. В. ${ }^{1}$ Шу Рим С. Г. ${ }^{2}$ \\ ${ }^{1}$ Сумський державний університет, м. Суми, Украӥна; \\ ${ }^{2}$ Університет Дуйсбург-Ессен, м. Ессен, Німеччина \\ kharchenko24t@gmail.com
}

Вступ. Діабетична нейропатія та ангіопатія - це основні патогенетичні фактори, що призводять до утворення трофічних виразок у хворих на цукровий діабет. Ішемія призводить до гіпоксії та недостатнього вивільнення факторів росту ендотелію судин (VEGF) та тромбоцитарного фрактору (PDGF) епітеліальними клітинами. Згідно сучасних досліджень, для загоєння трофічних виразок актуальним є використання аутологічної плазми, збагаченої фракторами росту.

Мета дослідження - оцінити ефективність комбінованої фотодинамічної терапії (ФДТ) та плазмотерапії, збагаченої факторами росту (PRGFT) для покращення якості життя пацієнтів із синдромом діабетичної стопи.

Матеріали і методи. У дослідження включено 61 паціент з цукровим діабетом 2 типу з синдромом діабетичної стопи II ступеня за Wagner. Пацієнти 1-ї групи (n = 30) отримували стандартну терапію (CT), у 2-й групі (n = 31) CT була доповнена ФДТ та PRGFT.

Результати. Використання ФДТ у комбінованому лікуванні хронічних виразок у хворих на ЦД покращуе очищення ранової поверхні у більш короткі терміни порівняно із СТ, що впливає на показники якості життя за шкалою EuroQol, категорію «фізична активність» поліпшило на 2,72 \%, «самообслуговування» - на 7,85 \%, «побутова активність» - на 7,06 \%, «біль/дискомфорт» — на 5,25 \% та категорії «тривожність/депресія» - на 19,74 \%. PRGFT було включено в комбіновану схему лікування після ФДТ для стимулювання епітеліалізації ранового дефекту у пацієнтів 2-ї групи. Ефективність заданого алгоритму підтверджено покращенням показників категорій шкали EuroQol: «фізична активність» на $18 \%$, «самообслуговування» — на 9 \%, «побутова активність» — на 9 \%, «біль/дискомфорт» на $15 \%$ та «тривожність/депресія» на $20 \%$. 
Висновки. Комбінована фотодинамічна терапія та плазмотерапія, збагачена факторами росту, є ефективнішою, у порівнянні з стандартною терапією, у лікуванні та покращенні якості життя хворих із синдромом діабетичної стопи.

Ключові слова: цукровий діабет, діабетична стопа, фотодинамічна терапія, аутологічна плазма.

\section{ДИНАМИКА КАЧЕСТВА ЖИЗНИ \\ У БОЛЬНЫХ С СИНДРОМОМ ДИАБЕТИЧЕСКОЙ СТОПЫ \\ ПРИ КОМБИНИРОВАННОМ ЛЕЧЕНИИ С ИСПОЛЬЗОВАНИЕМ ФИЗИОТЕРАПИИ И АУТОЛОГИЧЕСКОЙ ПЛАЗМЫ}

Харченко Т. А. ${ }^{1}$, Мелеховец О. К. ${ }^{1}$, Мелеховец Ю. В. ${ }^{1,}$ Радько А. С. ${ }^{1}$, Калашник Н. В. ${ }^{1}$, Шу Рим С. Г. ${ }^{2}$

${ }^{1}$ Сумской государственный университет, г. Сумь, Украина;

${ }^{2}$ Университет Дуйсбург-Эссен, г. Эссен, Германия

kharchenko24t@gmail.com

Введение. Диабетическая нейропатия и ангиопатия - это основные патогенетические факторы, которые приводят к образованию трофических язв у больных сахарным диабетом. Ишемия приводит к гипоксии и недостаточному высвобождению фракторов роста эндотелия сосудов (VEGF) и тробоцитарного фактора (PDGF) эпителиальными клетками. Согласно современным исследованиям, с целью заживления трофических язв, является актуальным использование аутологической плазмы, обогащенной фракторами роста.

Цель исследования - оценить әффективность комбинированной фотодинамической терапии (ФДТ) и плазмотерапии, обогащенной фракторами роста (PRGFT) для улучшения качества жизни пациентов с синдромом диабетической стопы.

Материалы и методы. В исследование включено 61 пациент с сахарным диабетом 2 типа с синдромом диабетической стопы II степени по Wagner. Пациенты 1-й группы (n = 30) получали стандартную терапию (CT), во 2-й группе $(\mathrm{n}=31) \mathrm{CT}$ была дополнена ФДТ и PRGFT.

Результаты. Применение ФДТ в комбинированном лечении хронических язв у больных СД улучшает очищение раневой поверхности в более короткие сроки, по сравнению с СТ, улучшает показатели качества жизни по шкале EuroQol, категорию «физическая активность» улучшило на 2,72 \%, «самообслуживания» - на 7,85 \%, «бытовая активность» - на 7,06 \%, «боль/дискомфорт» — на 5,25 \% и категории «тревожность/депрессия» - на 19,74 \%. PRGFT была включена в комбинированную схему лечения после ФДТ для стимуляции епителиализации раневого дефекта у пациентов 2-й группы. Эффективность данного алгоритма была подтверждена улучшением показателей категорий шкалы EuroQol: «физическая активность» - на 18 \%, «самообслуживания» — на 9 \%, «бытовая активность» на 9 \%, «боль/дискомфорт» на 15\% и «тревожность/депрессия» на 20 \%.

Выводы. Комбинированная фотодинамическая терапия и плазмотерапия, обогащённая фракторами роста является более эффективной, по сравнению со стандартной терапией, в лечении и улучшении качества жизни амбулаторных больных с синдромом диабетической стопы.

Ключевые слова: сахарный диабет, диабетическая стопа, фотодинамическая терапия, аутологическая плазма. 